\title{
molecules
}

ISSN 1420-3049

http://www.mdpi.org

Full Paper

\section{Solid Phase Synthesis of a Metronidazole Oligonucleotide Conjugate}

\author{
Andrew J. Walsh, Michael L. Davis and William Fraser * \\ School of Life and Health Sciences, Aston University, Aston Triangle, Birmingham, B4 7ET, UK \\ Tel.: +44 121204 3940, Fax. +44 1213590733
}

* Author to whom correspondence should be addressed; E-mail: w.fraser@aston.ac.uk

Received: 26 April 2006; in revised form: 23 May 2006 / Accepted: 29 May 2006 / Published: 23 June 2006

\begin{abstract}
Direct, solid phase synthesis of an oligonucleotide conjugate of the antibiotic drug metronidazole was accomplished by the phosphoramidite method. Removal of protecting groups and cleavage from the controlled pore glass (CPG) solid support was successful using mild conditions (20\% $\mathrm{Et}_{3} \mathrm{~N}$ in pyridine, then conc. $\mathrm{NH}_{3}$ (aq) at rt for 30 min) whereas standard conditions (conc. $\mathrm{NH}_{3}$ (aq) at $55^{\circ} \mathrm{C}$ for $16 \mathrm{~h}$ ) cleaved the drug.
\end{abstract}

Keywords: CPG, conjugate, metronidazole, oligonucleotide, phosphoramidite, solid phase.

\section{Introduction}

Nitroimidazoles, notably metronidazole (1), are important for the treatment of a wide range of anaerobic bacterial and protozoan infections due their ability to damage and cleave microbial DNA, selectively, under oxygen deficient conditions [1-4]. Although resistance to this class of drug is still low, there are reports of its increase [5-9], therefore improvements to delivery, targeting, localization and mode of action of such nitroimidazoles, would be beneficial [10]. With their ability to position within oxygen-deficient tissue, nitroimidazole derivatives have been investigated as chemotherapeutic agents and radiosensitizers in the treatment of hypoxic tumours [2,11,12]. Although studies suggest that metronidazole and its metabolites cause damage to DNA and mutagenicity in normal human cells, the data remain contradictory $[13,14]$. Solution chemistry has allowed attachment of the nitroimidazole ring system to oligopyrrole derivatives of the A.T selective, DNA minor groove binding antibiotic distamycin $[15,16]$. Such nitroimidazole oligopyrrole conjugates show high affinity for DNA but no 
improvement in radiosensitization over the unconjugated nitroimidazole [17]. Under anaerobic conditions, nitroimidazoles cause greatest DNA damage at A.T base pair sites. There is therefore scope to deliver nitroimidazoles specifically to such sites by forming conjugates with triplex forming oligoucleotides (TFOs) that bind in the major grove of DNA by Hoogsteen hydrogen bonding [18]. By using metronidazole as a representative nitroimidazole and $\mathrm{dT}_{8}$ as a model $\mathrm{TFO}$, the feasibility of conjugate formation by solid phase synthesis was assessed.

\section{Results and Discussion}

The required phosphoramidite derivative 2 , for use in solid phase synthesis, was formed directly by reaction of metronidazole (1) with 2-cyanoethyl- $N, N$-diisopropylchlorophosphoramidite in the presence of $\mathrm{N}, \mathrm{N}$-diisopropylamine using anhydrous conditions (Equation 1). Although the literature indicates a longer reaction time for the phosphitylation of the O3' hydroxyl group of nucleosides, analysis by TLC showed that the reaction was complete after $20 \mathrm{~min}$, reflecting the increased reactivity of the primary hydroxyl group of metronidazole over the secondary O3' hydroxyl group of nucleosides [19]. Purification of the metronidazole phosphoramidite 2 was achieved by flash column chromatography giving $\mathbf{2}$ in $89 \%$ yield. Analysis of $\mathbf{2}$ by NMR showed a single peak at $8.0 \mathrm{ppm}$ in the proton spectrum corresponding to $\mathrm{H} 4$. A single peak at $51.4 \mathrm{ppm}$ in the phosphorus NMR spectrum with no accompanying $\mathrm{H}$-phosphonate peaks, typically observed near $0 \mathrm{ppm}$, confirmed the identity of 2 and indicated high purity. The stability of 2 was confirmed during prolonged storage at $4{ }^{\circ} \mathrm{C}$ and subsequent re-analysis by proton NMR. Automated solid phase synthesis of the metronidazole oligonucleotide conjugate $\mathbf{3}$ on controlled pore glass (CPG) was performed using the standard phosphoramidite method [20].

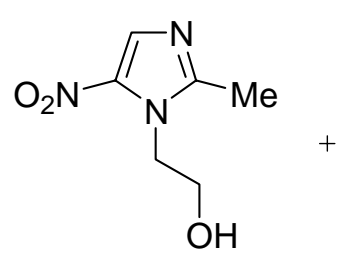

1
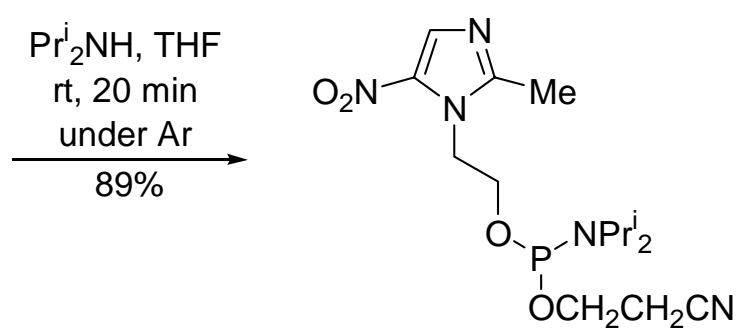

2

Aware of the potential danger to the nitroimidazole ring system that standard conditions for removal of the cyanoethyl protecting groups and release of the conjugate from the solid support might pose, 3 was divided into two portions. The first portion was subjected to standard deprotection/cleavage conditions: conc. $\mathrm{NH}_{3}$ (aq) at $55^{\circ} \mathrm{C}$ for $16 \mathrm{~h}$ (Scheme 1). Reversed phase (RP) HPLC analysis of the crude product (Figure 1, middle trace) showed one major component with a retention time $\left(t_{\mathrm{R}}\right)$ of $11.7 \mathrm{~min}$. The main component was purified by semi-preparative RP HPLC, and analysis by negative ion electrospray mass spectrometry (ESMS (-)) gave a molecular weight of 2494.1 corresponding to 4 with a calculated molecular weight of 2492.4. 


\section{Scheme 1.}
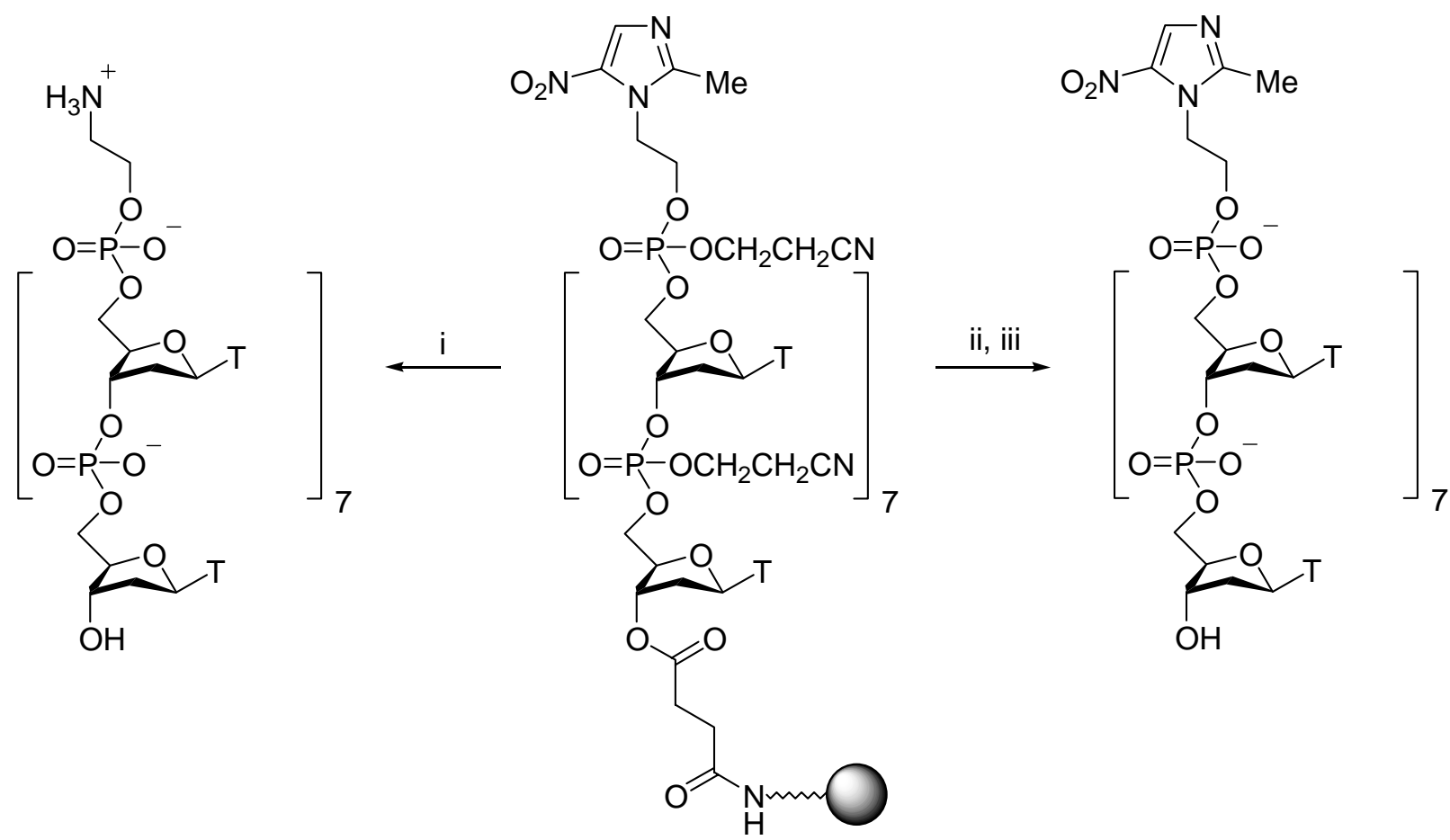

4

3

5

Reagents and conditions: (i) conc. $\mathrm{NH}_{3}$ (aq), $55^{\circ} \mathrm{C}, 16 \mathrm{~h}$; (ii) $20 \% \mathrm{Et}_{3} \mathrm{~N}$ in pyridine, $2 \mathrm{~h}$, rt; (iii) conc. $\mathrm{NH}_{3}(\mathrm{aq}), 30 \mathrm{~min}, \mathrm{rt}$.

Clearly, the nitroimidazole ring is not compatible with the standard conditions, therefore milder conditions for protecting group removal and release of the conjugate from the solid support were then applied to the remainder of 3 . Thus, 3 was treated firstly with $20 \% \mathrm{Et}_{3} \mathrm{~N}$ in pyridine at room temperature for $2 \mathrm{~h}$, to remove the cyanoethyl protecting groups, then with conc. $\mathrm{NH}_{3}(\mathrm{aq})$ at room temperature for $30 \mathrm{~min}$, to cleave the conjugate from the solid support. RP HPLC analysis of the crude product (Figure 1, upper trace) showed one major component with $t_{\mathrm{R}} 13.1 \mathrm{~min}$ and no accompanying minor components. ESMS (-) analysis confirmed the structure of the product as the target metronidazole oligonucleotide conjugate 5 with the molecular weight found, 2604.2, being within $0.1 \%$ of the calculated value 2603.4. Co-injection of $\mathbf{4}$ and conjugate 5 (Figure 1, lower trace) show the two to be clearly distinguished with $\mathbf{4}$ eluted before the marginally more lipophilic $\mathbf{5}$.

Displacement of the nitroimidazole ring in $\mathbf{3}$ by ammonia in a $S_{N} 2$ process to form $\mathbf{4}$ is least likely as ammonia is not a strong enough nucleophile and imidazole is too poor a leaving group, despite activation by the nitro substituent [21]. When the purified metronidazole conjugate 5 was treated with conc. $\mathrm{NH}_{3}$ (aq) at $16 \mathrm{~h}$ for $55^{\circ} \mathrm{C}$, and analysed by RP HPLC, no by-products other than 4 were observed at the detection wavelength $(260 \mathrm{~nm})$. A commercial sample of 2-methyl-5-nitroimidazole gave $t_{\mathrm{R}} 7.8$ min under the same RP HPLC analysis conditions. 
Figure 1. Reversed phase HPLC profiles of the target metronidazole oligonucleotide conjugate 5 with retention time $13.1 \mathrm{~min}$ (upper trace), aminoethyl oligonucleotide conjugate 4 with retention time 11.7 min (middle trace) and a co-injection of both conjugates 4 and 5 (lower trace). The vertical axes show milliabsorbance units (mAU) and the horizontal axes show retention time.
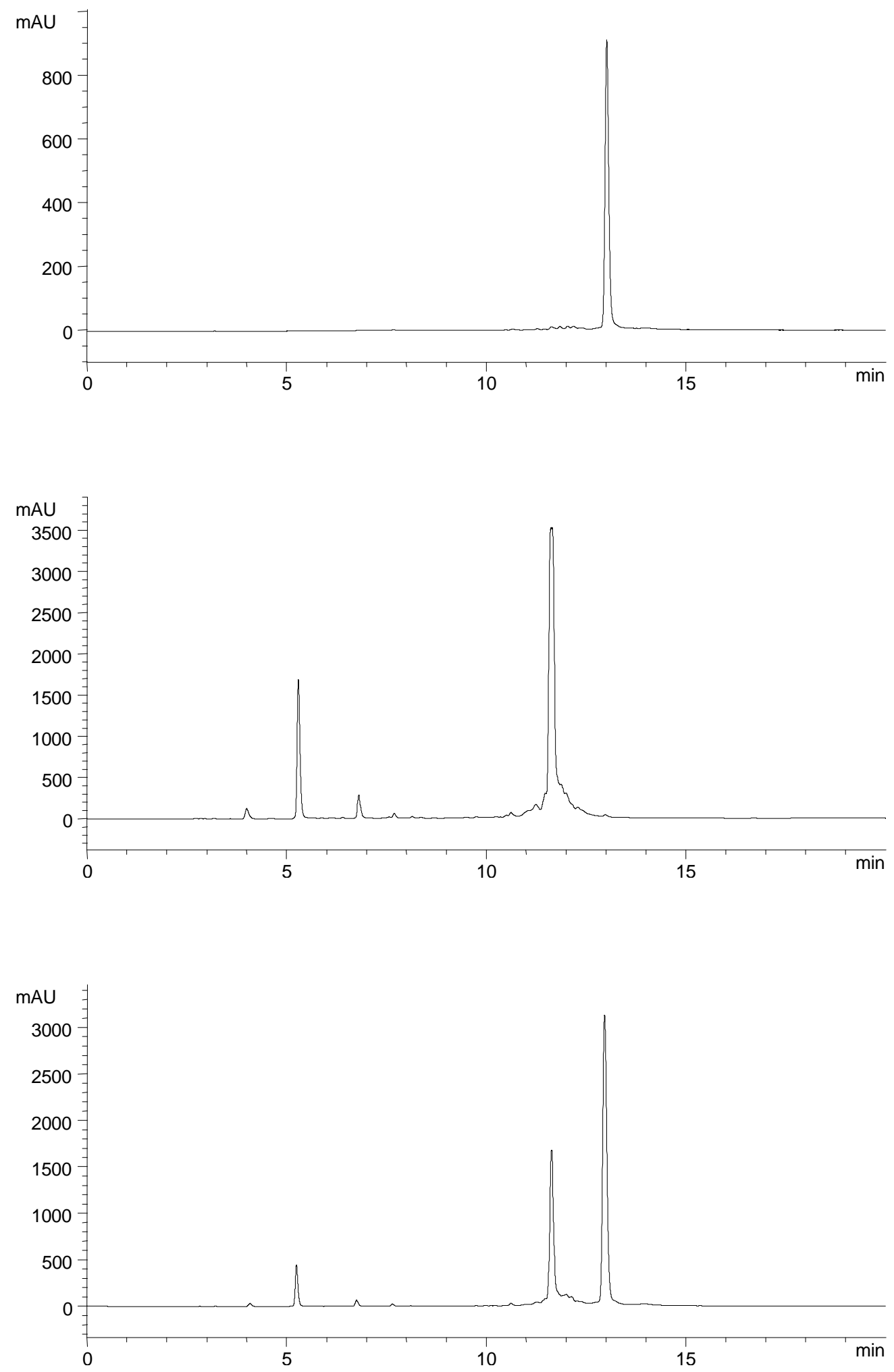
When refluxed with 4-dimethylaminopyridine (DMAP), 2-bromo-4,5-dicyanoimidazole undergoes substitution at C2 with concomitant detachment of its N1 methyl group, albeit in low yield (38\%) (Equation 2), because the 4,5-dicyanoimidazole anion is a better leaving group than a singly activated imidazole ring [22]. Formation of $\mathbf{4}$ from $\mathbf{3}$ is therefore most likely to be due to fragmentation of the nitroimidazole ring.<smiles>Cn1c(Br)nc(C#N)c1C#N</smiles>

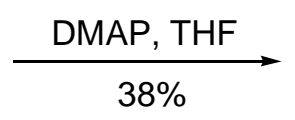<smiles>N#Cc1nc(-[n+]2ccc(N)cc2)[nH]c1C#N</smiles>

The reactivity of metronidazole (1) towards various nucleophiles is well documented in the literature [21,23] but not, as far as we are aware, its reactivity towards aqueous ammonia. The literature shows that attack on the nitroimidazole ring system is possible at C2, C4 or C5 but is heavily dependant on the other substituents present and the particular nucleophile employed. Use of liquid ammonia allows replacement of the methylsulfonyl group with amino at C2 (Equation 3) [23]. When sulphur nucleophiles such as cysteine are employed, it is reported that replacement of the 5-nitro group occurs in a pH-dependent manner (Equation 4) [24]. Thiol-mediated nitro group displacements are known to occur readily in appropriately substituted benzene and other aromatic rings by the classical addition/elimination mechanism [25]. By contrast, 1,2-dimethyl-5-nitroimidazole reacts with hydroxyl-amine to give the corresponding 4-amino derivative (Equation 5) [26].<smiles>COS(=O)(=O)c1ncc([N+](=O)[O-])n1C</smiles><smiles>Nc1ccccc1</smiles><smiles>Cn1c([N+](=O)[O-])cnc1N</smiles><smiles>Cc1ncc([N+](=O)[O-])n1C</smiles><smiles>CC(C)([SiH3])Cl</smiles><smiles>Cc1ncc(SC2CCCCC2)n1C</smiles><smiles>Cc1ncc([N+](=O)[O-])n1C</smiles><smiles>Cc1nc(N)c([N+](=O)[O-])n1C</smiles> 
Metronidazole (1) has been reported to react with hydrazine by attack at C4 to give a separable mixture of 1-amino-2,5-dimethyl-1,3,4-triazine, glyoxal dihydrazone and ethanolammonium nitrite (Equation 6) with similar reactivity towards hydrazine being observed for 1,2-dimethyl-5nitroimidazole [27]. Involvement of a bicyclic intermediate during hydrazine-mediated ring fragmentation of $\mathbf{1}$ is proposed, as near quantitative recovery of $\mathbf{1}$ was achieved after exposure to neat 1,1-dimethylhydrazine ( $28 \mathrm{~h}, 55^{\circ} \mathrm{C}$ ). Similarly, 1 was recovered (86\%) after exposure to benzylamine in THF $\left(17 \mathrm{~h}, 63^{\circ} \mathrm{C}\right)$ [27].
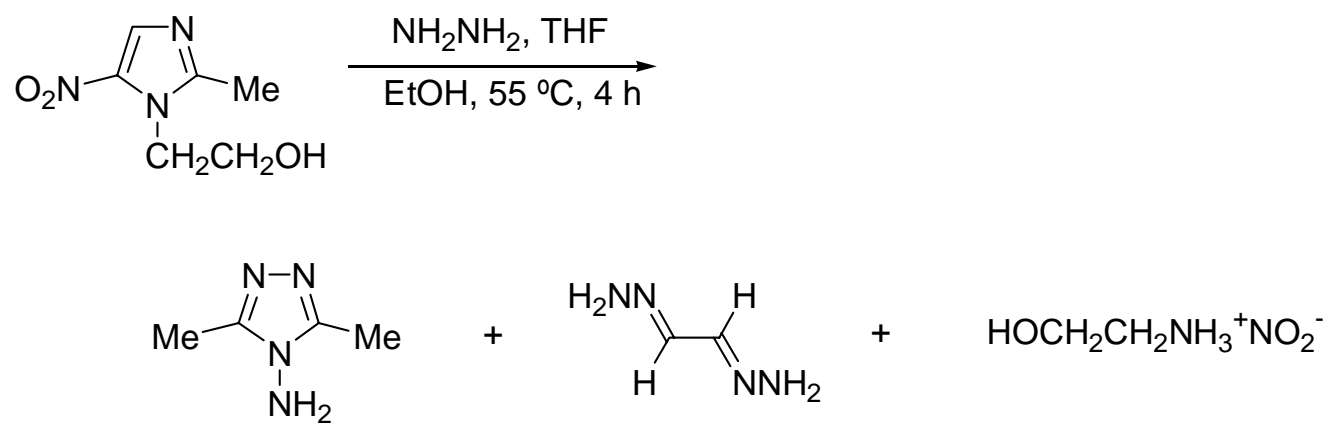

Comparison of the X-ray crystal structure of tinidazole (6) [28] with that of imidazole reveals a shortened C3-C4 bond and lengthened C4-C5 bond, perhaps due to a contribution from structure 7 [23]. Formation of $\mathbf{4}$ from $\mathbf{3}$ is therefore most likely due to fragmentation of the nitroimidazole ring but it is not clear which position of nitroimidazole ring, $\mathrm{C} 2, \mathrm{C} 4$ or $\mathrm{C} 5$, undergoes initial attack in conc. $\mathrm{NH}_{3}$ (aq).

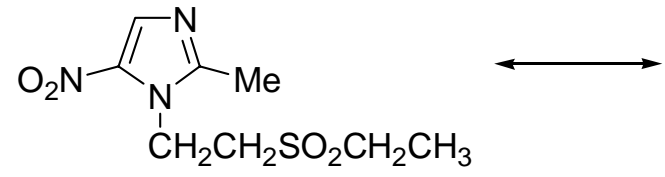

6<smiles></smiles>

7

General applicability of this method for solid phase synthesis of metronidazole conjugates of oligonucleotides containing each of the other DNA bases in addition to $\mathrm{T}$ is expected because commercially available [29] A, C and G phosphoramidites contain formamidine or phenoxyacetyl protecting groups, which are cleaveable under the conditions that are compatible with metronidazole. Alternatively, the need to use ammonia may be completely avoided by using a solution of lithium hydroxide $(0.5 \mathrm{M})$ and triethylamine $(3.5 \mathrm{M})$ in methanol at $70{ }^{\circ} \mathrm{C}$ for one hour [30]. These conditions are compatible with standard phosphoramidites containing benzoyl protected A and C, and isobutyryl protected $\mathrm{G}$ bases [30].

\section{Acknowledgements}

We thank the Cancer Research Campaign (now Cancer Research UK) for a studentship (AJW). 


\section{Experimental}

\section{General}

${ }^{1} \mathrm{H}$ and ${ }^{31} \mathrm{P}$-NMR spectra were recorded on a Bruker AC250 spectrometer at 250.1 and $101.3 \mathrm{MHz}$, respectively. Positive chemical shifts are downfield of tetramethylsilane for ${ }^{1} \mathrm{H}$ and downfield of $85 \%$ (aq) $\mathrm{H}_{3} \mathrm{PO}_{4}$ for ${ }^{31} \mathrm{P}$. Negative ion electrospray mass spectrometric analysis was carried out on Hewlett Packard HP 5989B MS Engine apparatus using a HP 59987A API electrospray LC/MS interface. Flash column chromatography was performed using Sorbsil C60 silica gel [31]. TLC was performed using plastic-backed Kieselgel 60 silica gel plates containing a fluorescent indicator and visualised under UV (254 nm). DNA synthesis was performed on a Beckman Oligo 1000 Synthesiser following the manufacturer's protocol [32]. HPLC was carried out on a Hewlett Packard Series 1100 instrument with the UV detection wavelength set at $260 \mathrm{~nm}$. Gradient elution was performed on a HPLC Technology C18 Reversed Phase Column ( $250 \times 4.6 \mathrm{~mm})$ at a flow rate of $1 \mathrm{~mL} \mathrm{~min}^{-1}$ where solvent system A was mixed 0-40\% with solvent system B during $20 \mathrm{~min}$. Solvent system A was composed of $1 \mathrm{M}$ aqueous triethylammonium acetate (TEAA, 10\%) and $\mathrm{MeCN}(2 \%)$ at $\mathrm{pH} 7.0$, and solvent system B was composed of $1 \mathrm{M}$ aqueous TEAA (10\%) and MeCN (80\%) at $\mathrm{pH}$ 7.0. Semi-preparative purification was carried out by dissolving the oligonucleotide in $\mathrm{H}_{2} \mathrm{O}(1.5 \mathrm{~mL})$ and injecting aliquots (typically 0.3 to $0.5 \mathrm{~mL}$ ) using a $1 \mathrm{~mL}$ injection loop and syringe. All solvent and column conditions were as above, except that the UV detection wavelength was at $285 \mathrm{~nm}$. Purified oligonucleotides were desalted using Waters' SepPak columns.

Preparation of 2-(2-methyl-5-nitroimidazoyl)-ethyl-(2-cyanoethyl)-N,N-diisopropyl)-phosphoramidite (2)

2-Cyanoethyl- $N, N$-diisopropylchlorophosphoramidite $(0.37 \mathrm{~g}, 4.65 \mathrm{mmol})$ was added to a stirred solution of metronidazole (0.53 g, $3.1 \mathrm{mmol})$ and diisopropylamine (0.31 g, $9.1 \mathrm{mmol})$ in dry THF (15 $\mathrm{ml}$ ) under Ar. After stirring for $1 \mathrm{~h}$ at $\mathrm{rt}$ the reaction mixture was evaporated under reduced pressure and dried under high vacuum. The metronidazole phosphoramidite 2 (1.02 g, 89\%) was isolated by flash column chromatography (EtOAc) and dried under high vacuum. TLC (EtOAc) $\mathrm{R}_{f} 0.38 ;{ }^{1} \mathrm{H}-\mathrm{NMR}$ [( $\left.\left(\mathrm{CD}_{3}\right)_{2} \mathrm{SO}\right]: \delta 1.03\left(12 \mathrm{H}, \mathrm{m}, 4 \times \mathrm{CH}_{3}\left(\mathrm{Pr}^{\mathrm{i}}\right)\right), 2.50\left(3 \mathrm{H}, \mathrm{s}, 2-\mathrm{CH}_{3}\right), 2.71\left(2 \mathrm{H}, \mathrm{t}, J=5.8 \mathrm{~Hz}, \mathrm{OCH}_{2} \mathrm{CH}_{2} \mathrm{Ar}\right)$, $3.43\left(2 \mathrm{H}, \mathrm{m}, \mathrm{OCH}_{2} \mathrm{CH}_{2} \mathrm{CN}\right), 3.62\left(2 \mathrm{H}, \mathrm{m}, 2 \times \mathrm{CHPr}_{2}^{\mathrm{i}}\right), 3.85\left(2 \mathrm{H}, \mathrm{m}, \mathrm{OCH}_{2} \mathrm{CH}_{2} \mathrm{CN}\right), 4.51(2 \mathrm{H}, \mathrm{t}, J=$ $\left.5.8 \mathrm{~Hz}, \mathrm{OCH}_{2} \mathrm{CH}_{2} \mathrm{Ar}\right), 8.04 \mathrm{ppm}(1 \mathrm{H}, \mathrm{s}, 4-\mathrm{H}(\mathrm{Ar}))$; ${ }^{31} \mathrm{P}-\mathrm{NMR}$ [( $\left.\left(\mathrm{CD}_{3}\right)_{2} \mathrm{SO}\right]: \delta 51.45 \mathrm{ppm}(\mathrm{s})$.

\section{Preparation of protected, solid supported metronidazole oligonucleotide conjugate 3}

Synthesis of solid supported conjugate 3 was achieved by the standard phosphoramidite method [20,32] on a $1000 \mathrm{nM}$ scale using CPG derivatised with dT (28 mg). The metronidazole phosphoramidite 2 (0.1 $\mathrm{M}$ in $\mathrm{MeCN})$ was used during the final coupling step. The solid CPG support was dried using a stream of Ar then divided into two portions for the following deprotection/cleavage steps. 


\section{Preparation of aminoethyl oligonucliotide conjugate 4}

To solid supported conjugate 3 (10 mg) was added conc. $\mathrm{NH}_{3}(\mathrm{aq})$ and the mixture heated in a sealed tube at $55{ }^{\circ} \mathrm{C}$ during $16 \mathrm{~h}$. The product was purified by semi-preparative HPLC affording 4 (22 O.D.); RP HPLC: $t_{\mathrm{R}} 11.7$ min; ESMS (-): calculated 2492.4, found 2494.1.

\section{Preparation of metronidazole oligonucleotide conjugate 5}

To the solid supported conjugate 3 (17 mg) was added $20 \% \mathrm{Et}_{3} \mathrm{~N}$ in pyridine $(1 \mathrm{~mL})$ and the mixture was gently swirled at rt for $2 \mathrm{~h}$. The solid support was then washed with MeCN ( $\mathrm{x} 1 \mathrm{~mL})$ then $\mathrm{Et}_{2} \mathrm{O}(2 \times 1 \mathrm{~mL})$ and left to dry in the air. Concentrated $\mathrm{NH}_{3}(\mathrm{aq})$ was then added to the support 3 and the mixture was then left at rt for $30 \mathrm{~min}$. The product was purified by RP HPLC affording 5 (5 O.D.); HPLC: $t_{\mathrm{R}} 13.1 \mathrm{~min}$; ESMS (-): calculated 2603.4, found 2604.2. The HPLC profile of coinjected $\mathbf{4}$ and $\mathbf{5}$ showed two distinct peaks.

\section{References}

1. Edwards, D. I. Nitroimidazole drugs - action and resistance mechanisms I. Mechanisms of action. J. Antimicrob. Chemother. 1993, 31, 9-20.

2. Tocher, J. H. Reductive activation of nitroheterocyclic compounds. Gen. Pharmacol. 1997, 28, 485-487.

3. Pendland, S. L; Piscitelli, S. C.; Schreckenberger, P. C.; Danziger, L. H. In vitro activities of metronidazole and its hydroxyl metabolite against Bacteroides spp. Antimicrob. Agents Chemother. 1994, 38, 2106-2110.

4. Oliveira, R. B.; Passos, A. P. F.; Alves, R. O.; Romanha, A. J.; Prado, M. A. F.; de Souza Filho, J. D.; Alves, R. J. In vitro evaluation of the activity of aromatic nitrocompounds against Trypanosoma cruzi. Memorias-Inst. Oswaldo Cruz, Rio de Janeiro 2003, 98, 141-144.

5. Sóki, J.; Gal, M.; Brazier, J. S.; Rotimi, V. O.; Urbán, E.; Nagy, E.; Duerden, B. I. Molecular investigation of genetic elements contributing to metronidazole resistance in Bacteroides strains. $J$. Antimicrob. Chemother. 2006, 57, 212-220.

6. Sisson, G.; Jeong, J.-Y., Goodwin, A.; Bryen, L.: Rossler, N.; Lim-Morrison, S.; Raudonikiene, A.; Berg, D. E.; Hoffman, P. S. Metronidazole activation is mutagenic and causes DNA fragmentation in Helicobacter pylori and in Escherichia coli containing a cloned H. pylori $r d x A^{+}$ (nitroreductase) gene. J. Bacteriol. 2000, 182, 5091-5096.

7. Osato, M. S; Reddy, R.; Graham, D. Y. Metronidazole and clarithromycin resistance amongst Helicobacter pylori isolates from a large metropolitan hospital in the Unites States. Int. J. Antimicrob. Agents 1999, 12, 341-347.

8. Reysset, G. Genetics of 5-nitroimidazole resistance in Bacteroides species. Anearobe 1996, 2, 5969.

9. Dachs, G. U.; Abratt, V. R.; Woods, D. R. Mode of action of metronidazole and a Bacteroides fragilis metA resistance gene in Escherichia coli. J. Antimicrob. Chemother. 1995, 35, 483-496.

10. Bowden, K.; Izadi, J. Multifunctional derivatives of metronidazole. Farmaco 1998, 53, 58-61. 
11. Parrick, J.; Porssa, M. Synthesis of polyamine derivatives of 2-nitroimidazole as DNA-directed radiosensitisers. J. Chem. Res. (S) 1995, 186-187.

12. Ali, H.; Ouellet, R.; DaSilva, J. N.; van Lier, J. E. Synthesis of steroidal nitroimidazoles as siteselective radiosensitisers. J. Chem. Res. (S) 1993, 92-93.

13. Menéndez, D.; Rojas, E.; Herrera, L. A.; López, M. C.; Sordo, M.; Elizondo, G.; OstroskyWegman, P. DNA breakage due to metronidazole treatment. Mutat. Res. 2001, 478, 153-158.

14. Connor, T. H.; Stoeckel, M.; Evrard, J.; Legator, M. S. The contribution of metronidazole and two metabolites to the mutagenic activity detected in urine of treated humans and mice. Cancer Res. 1977, 37, 629-633.

15. Parrick, J.; Porssa, M. Synthesis of a nitro oligo- $N$-methylimidazole carboxamide derivative: A radiosensitiser targeted to DNA. Tetrahedron Lett. 1993, 34, 5011-5014.

16. Parrick, J.; Porssa, M.; Jenkins, T. M. The synthesis of radiosensitizers designed to bind to the minor groove of duplex DNA. J. Chem. Soc., Perkin Trans. 1 1993, 2681-2685.

17. Parrick, J.; Porssa, M.; Davies, L. K.; Dennis, M. F., Patel, K. B.; Stratford, M. R. L.; Wardman, P. Targeting radiosensitizers to DNA by minor groove binding: Nitroarenes based on netropsin and distamycin. Bioorg. Med. Chem. Lett. 1993, 3, 1697-1702.

18. Da Ros, T.; Spalluto, G.; Prato, M.; Saison-Behmoaras, T.; Boutorine, A.; Cacciari, B. Oligonucleotides and oligonucleotide conjugates: A new approach for cancer treatment. Curr. Med. Chem. 2005, 12, 71-88.

19. Neeley, W. L.; Henderson, P. T.; Essigmann, J. M. Efficient synthesis of DNA containing the guanine oxidation-nitration product 5-guanidino-4-nitroimidazole: Generation by a postsynthetic substitution reaction. Org. Lett. 2004, 6, 245-248.

20. Atkinson, T.; Smith, M. In Oligonucleotide Synthesis. A Practical Approach; Gait, M. J., Ed.; IRL Press: Oxford, 1984; Chapter 3, pp. 35-81.

21. Grimmett, G. M. In Comprehensive Heterocyclic Chemistry; Katrizky, A. R.; Rees, C. W.; Scriven, E. F. V., Eds.; Elsevier: Oxford, 1984; Vol. 5, Chapter 4.07, pp. 373-456.

22. Apen, P. G.; Rasmussen, P. G. Nucleophilic aromatic-substitution in 4,5-dicyanoimidazoles. Heterocycles 1989, 29, 1325-1329.

23. Grimmett, G. M. In Comprehensive Heterocyclic Chemistry; Katrizky, A. R.; Rees, C. W.; Scriven, E. F. V., Eds.; Elsevier: Oxford, 1996; Vol. 3, Chapter 3.02, 1996, pp. 373-456.

24. Girard, M.; Clarimont, F.; Maneckjee, A.; Mousseau, N.; Dawson, B. A.; Whitehouse, L. W. 5Nitroimidazoles II: Unexpected reactivity of ronidazole and dimetridazole with thiols. Can. J. Chem. 1993, 71, 1349-1352.

25. Beck, J. R. Nucleophilic displacement of aromatic nitro groups. Tetrahedron, 1978, 34, 20572068.

26. Sunjić, V.; Fajdiga, T.; Japelj, M.; Rems, P. Nucleophilic substitutions in some derivatives of 4and 5-nitroimidazoles. J. Heterocycl. Chem. 1969, 6, 53-60.

27. Goldman, P.; Ramos, S. M.; Wuest, J. D. Reactions of nitroimidazoles with hydrazine. J. Org. Chem. 1984, 49, 932-935.

28. Chasseaud, L. F.; Henrick, K.; Matthews, R. W.; Scott, P. W.; Wood, S. G. Metabolic ring hydroxylation of tinidazole involving a novel nitro-group migration: X-ray structures of tinidazole and the $\mathrm{NH}_{4}{ }^{+}$salt of its ring hydroxylated metabolite. Chem. Commun. 1984, 491-492. 
29. '2005 Product Guide’, Link Technologies, 2005. Available online: http://www.linktech.co.uk [Accessed April 2006].

30. Surzhikov, S. A.; Timofeev, E. N.; Chernov, B. K.; Golova, J. B.; Mirzabekov, A. D. Advanced method for oligonucleotide deprotection. Nucleic Acids Res. 2000, 28, e29.

31. Still, W. C.; Kahn, M.; Mitra, A. Rapid chromatographic technique for preparative separations with moderate resolution. J. Org. Chem. 1978, 43, 2923-2925.

32. 'Oligo 1000 DNA Synthesiser Operating Instructions', Beckman Instruments Incorporated, 1994.

Sample availability: Please contact the authors.

(c) 2006 by MDPI (http://www.mdpi.org). Reproduction is permitted for noncommercial purposes. 